\title{
Information and Communication Technology Recommendations for the Further Development of a Robust National Electronic Health Strategy for Epidemics and Pandemics
}

\author{
Putu Wuri Handayani* \\ Faculty of Computer Science \\ Universitas Indonesia \\ putu.wuri@cs.ui.ac.id \\ Stéphane Bressan \\ School of Computing \\ National University of Singapore \\ steph@nus.edu.sg
}

\author{
Setiadi Yazid \\ Faculty of Computer Science \\ Universitas Indonesia \\ setiadi@cs.ui.ac.id
}

Agung Firmansyah Sampe
Management of Complex Projects
University College London
agung.sampe.19@ucl.ac.uk

\begin{abstract}
This paper aims to provide recommendations for information and communication technology strategy that can support government actions to overcome epidemics and pandemics in Indonesia. The method used in this research is a qualitative approach by conducting a narrative review and discussion with four experts in the field of information and communication technology. The results of this study are recommendations related to people, process, technology, and data. The recommendations are inspired by the success of Internet in establishing public and private collaboration. This research is intended to assist the government in formulating information and communication technology policies to support government and health organization actions to overcome epidemics and pandemics.
\end{abstract}

Keywords: Information and communication technology, recommendation, epidemic, pandemic, Indonesia

\section{Introduction}

The geography and demography of Indonesia compel the Indonesian government to create policies that leverage information and communication technologies (ICT) for the management of public health (Mahendradhata et al. 2017; Nugraha and Aknuranda 2017). The COVID-19 pandemic cruelly demonstrates the need for a sovereign, effective and efficient electronic health (e-health) infrastructure. While some national initiatives started as early as in the mid-eighties, in 2017 Minister of Health Regulation Number 46 primed the pump for the development of a national e-health strategy. Already multinational corporations are preparing their offer for a private e-health system (e.g. Deloitte Indonesia et al. 2019). However, as the regulation only defines the principles, to be operational there is a need to define and implement the detailed steps. Therefore, comprehensive, and integrated policies and regulations related to information technology and information systems are needed for all stakeholders in implementing e-health.

\footnotetext{
${ }^{*}$ Corresponding Author
} 
Based on the World Health Organization (WHO 2017), the definition of an epidemic is a plague that spreads over a wider geographical area, whereas a pandemic is an epidemic spreading to several countries or regions in the world. The crisis caused by epidemics and pandemics made all organizations and communities work together to solve these problems. Epidemics and pandemics can cause crises in a country where the country's leaders will face unknown and poorly understood problems (D'Auria and De Smet 2020). Moreover, the involvement of the communities in utilizing the ICT also very much needed in overcoming this epidemic and pandemic problems (D'Auria and De Smet 2020).

To date, the fact that Indonesia is one of Southeast Asia countries that has the highest COVID-19 positive patients where more than 2 percent compared to the total number of cases divided by the total population and more than 1 percent of mortality rate compared to the total number of cases divided by the total population has put pressure on the Indonesian government to have faster action in detecting and handling COVID-19 patients (Gugus Tugas Percepatan Penanganan COVID-19 2020). To overcome COVID-19, the Indonesian government has issued several regulations, one of which is Government Regulation No. 21 of 2020 namely Large-scale Social Restrictions to stop the spread of COVID-19. In addition, The Ministry of Health has also issued the Regulation No. 9 of 2020 namely Large-scale Social Restrictions Guidance. Based on Ministry of Health Regulation No. 9 of 2020, the primary data that need to be managed for handling epidemics and pandemics are medical records and personal health records ("resume medis"), travel history, disaster areas and list of areas in surveillance, number of cases and local transmission events. Based on those regulations, data related to infrastructure (medical devices, medicines, health facilities, laboratories, pharmacies, funerals, etc.) and the availability of human resources for medical personnel, analysts, and information technology are also vital for evaluating and monitoring health services provided by the health service manager.

Considering the importance of ICT in managing the COVID-19 pandemic in Indonesia and to fill in the gaps where only few studies have been conducted to provide ICT recommendation for the development of e-health in Indonesia (Sudarto et al. 2018), this study aims to provide recommendations for ICT solutions that can support the government's actions to overcome epidemics and pandemics in Indonesia. This research intends to assist the government and health organization in Indonesia and other countries that have the same characteristics as Indonesia in developing ICT policies to deal with epidemics and pandemics, especially COVID- 19 .

\section{Literature Review}

\section{Public Health}

Public health is what we as society do collectively to assure the conditions in which people can be healthy (IMO 1998). According to the States of America Center for Disease Control and Prevention (2011), public health has three core functions: assessment, policy, and assurance (Figure 1). Assessment consists in monitoring health as well as investigating, diagnosing, and solving health problems and health hazards in the national community. Accurate and periodic assessment of the community's health status consists of identification of health risks, attention to vital statistics and disparities as well as identification of assets and resources. Public health assessment use of methods and technology to interpret and communicate data. Diagnose and investigate health problems include the timely identification and investigation of health threats, availability of diagnostic service and response plans to address major health threats. Moreover, in the assessment process, health education and health promotion should be conducted within the community to support healthy living (e.g. using social marketing and media advocacy).

Policy development is conducted to protect health and guide public health practice. The scope of policy development includes community and state improvement planning and emergency response planning. Policy development consists in developing policies and plans to support both individual and community health efforts, mobilizing community partnerships and actions to contribute to the assessment as well as preparing people through information, education, and empowerment.

Assurance consists in enforcing laws and regulations that protect health and ensure safety, making sure that health services are available and provided, assuring a competent workforce and infrastructure, evaluating 
the effectiveness, accessibility, and quality of health services and researching for new insights and innovative solutions to health problems. In order to make sure that health services are available and provided, several actions should be done such as identification of populations with barriers to care, effective entry into a coordinated system of clinical care, ongoing care management and culturally appropriate and targeted health information for at risk population groups. Furthermore, continuing education and life-long learning to assure a competent workforce should be conducted by leadership development and cultural competence. Evaluation must be ongoing and should examine personal health service, population-based services, and the public health system. The most important linkages between public health practice and academic/research settings deem required to find innovative solutions to health problems.

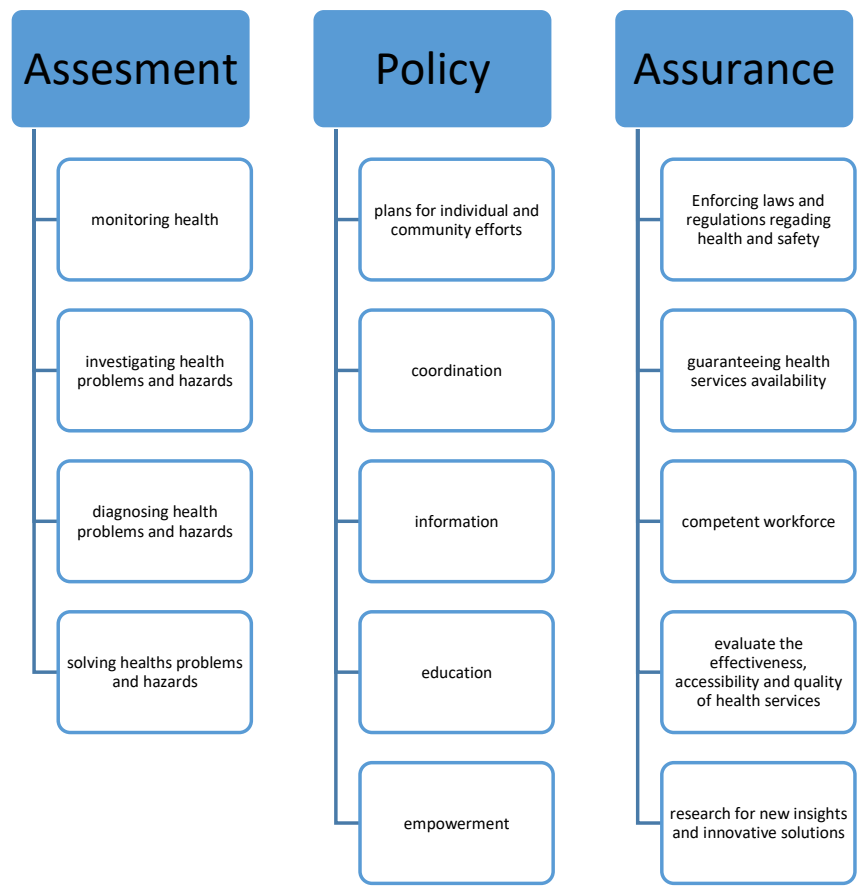

Figure 1. Public health functions (United States of America Center for Disease Control and Prevention 2011)

\section{Information systems and health information systems}

While different authors (e.g. Bardhan et al. 2020; Kang'a et al. 2017; Silver et al. 1995), considering different levels of granularity and choosing different emphasis, count different numbers of main components of an information system, we retain the following four: people, processes, technology and data (Figure 2). People include the general population or community, health workers, and researchers (Bardhan et al. 2020; Kang'a et al. 2017). Technological advances and regulatory shifts are transforming healthcare practices from being provider-centered to being patient centered, providing care that is respectful of and responsive to individual patient preferences, needs and values, and ensuring that patient values guide all clinical decisions (Bardhan et al. 2020). Furthermore, online health communities could provide patients feedback that can spawn medical innovation and creative insights (Bardhan et al. 2020). Thus, according to Kang'a et al. (2017), the people's issues are information and training and availability.

Processes bring issues like availability, software engineering and system design principles and requirements (e.g. privacy by design), design, operating and reporting standards, open source, security, data migration, algorithm explainability and responsibility (Kang'a et al. 2017). Those issues could be classified into design, implementation, and assurance of IS/IT development. According to Bardhan et al. (2020), there is critical need for connecting multiple health systems and data, including physiological signals (heart rate, blood pressure, etc), genomic biomarkers, electronic health record, radiology, and patient-reported social media content. Thus, system interoperability is also critical to develop a health information system. Hence, technologies include hardware and software for sensing, communication, computing, and control (Bardhan et al. 2020; Kang'a et al. 2017). Data brings issues such as open standards, quality, integrity, confidentiality, 
privacy, ownership, and cost (Bardhan et al. 2020; Kang'a et al. 2017). According to Bardhan et al. (2020), patient privacy must be protected to ensure the acceptance of technology.

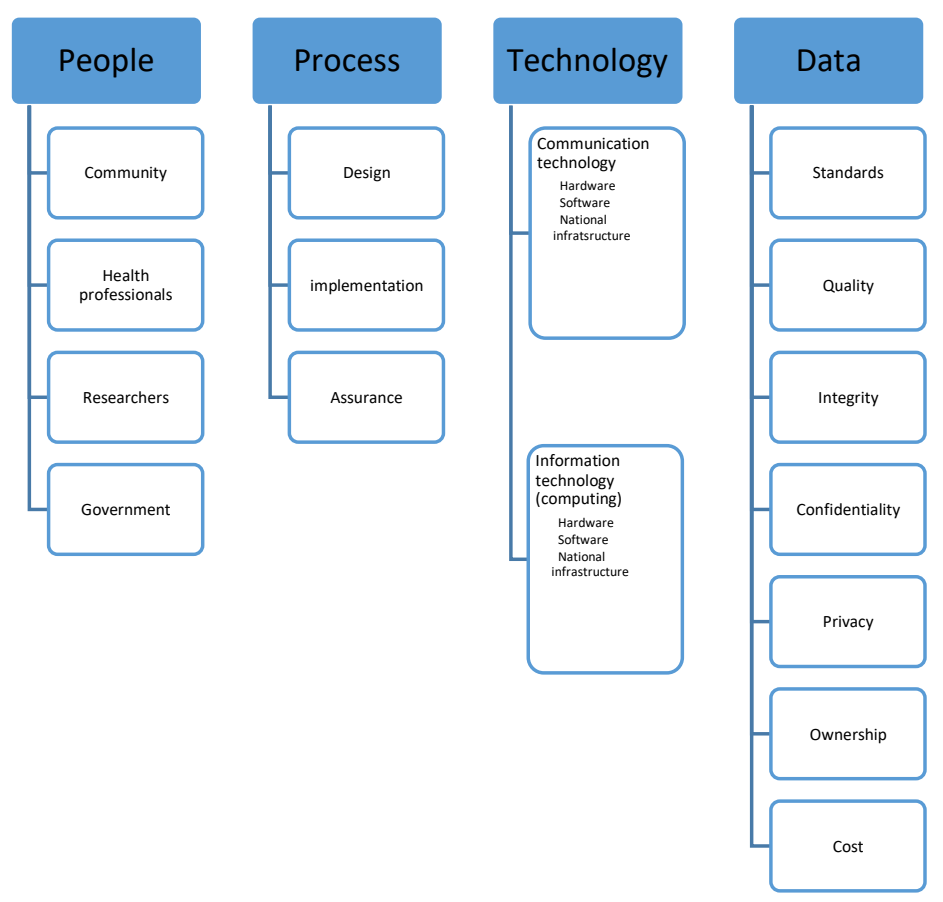

Figure 2. Information systems principles (Bardhan et al. 2020; Kang'a et al. 2017; Silver et al. 1995)

Silver et al. (1995), considering a functional system theoretic approach, recommend another perspective for the proactive design of information systems and their reactive analysis. The model that they propose considers information technology as an interaction between the information system and five elements of the organizations: the external environment, the strategy, the structure and culture, the processes and the information (and communication) technology infrastructure. The model induces a methodology that considers the following essentials: system effects, organizational context, features of the information system, fit between the features and the organizational context and the implementation process. In the case of a national health information system, these elements correspond to the foreign countries and foreign and international companies and organizations, the public health policy, and the national, public, and private, ICT infrastructure, respectively.

\section{Methodology}

We propose a methodology for the formulation of recommendations for the further development of a robust national e-health strategy from the point of view of ICT. The methodology is particularly designed to address the urgency arising from epidemics and pandemics. The methodology is principled: it identifies individual issues as the intersection between the components of the national health information system, to be understood as the de facto aggregation of people, processes, technology and data involved in and concerned by public health, and the three functions of public health, assessment, policy and assurance. We propose to adopt seven ethics principles and eight design principles to define the recommendations.

Further, this research uses a qualitative approach by conducting a narrative review and discussion with four experts in the fields of ICT. Prior to reviewing scientific publications papers, authors conducted reviews on Indonesia's regulations as well as other countries' and international agencies' regulations to develop recommendations that can comply with these regulations. The inclusion criteria used in the narrative review are by selecting online databases that focus on health research, selecting keywords and screening the fulltext paper obtained. The online databases used are MEDLINE/PUBMED and SCOPUS. Keywords used are related to health information technology, epidemics, and pandemics. Following the review, analyzing and considering the relevant prevailing regulations and previous researches with respect to the subject 
matters, the next step is to obtain inputs from four experts in ICT, who have more than 15 years experiences in their relevant fields which two of them are also lecturers at the Faculty of Computer Science University Indonesia. After the online interview with the experts, we classified the inputs by grouping the recommendations into people, processes, technology, and data. We analyze the data using content analysis to organize the meaning from data collected and to draw conclusions from it. Finally, we validated our results by conducting an online interview with those experts.

\section{Result}

\section{State of Indonesia e-health}

At present, the Ministry of Health has developed several e-health applications such as public health center information systems, hospital management information systems, health referral information systems, emergency information system and telemedicine that can be used by the public health care facilities. In addition, the Ministry of Health in collaboration with the National Health Social Security Agency also developed claims applications including COVID-19 data reporting applications. Public health care facilities also develop their own information systems in the management of health services. The private sector also participates in developing health and mobile health information systems that can be accessed by health care facilities and their patients. Further, the Ministry of Health also has a health service facility performance reporting application where every health care facility is required to report on their activities annually. These applications can be used to assist the government in performing public health functions according to the States of America Center for Disease Control and Prevention (2011).

In Indonesia, there are several implementing regulations on e-health covering the aspects of health, development of information system/information technology, health information system, and COVID-19 (Figure 3). Currently, there are 17 implementing regulations on e-health. Regulations on health in general are governed by the following regulations: Presidential Regulation No. 72 of 2012 on the National Health System, Minister of Health Regulation No. 269 of 2008 on Medical Records and Minister of Health Regulation No. 73 of 2016 on Pharmaceutical Services Standards at Pharmacies. Presidential Regulation No. 72 of 2012 provides the definition of the National Health System as a health management that is carried out by all components of the Indonesian people in an integrated and mutually supportive manner to ensure the highest possible level of public health. Minister of Health Regulation No. 269 of 2008 describes that a medical record is a file containing records and documents about patient identity, examination, treatment, actions, and other services provided to patients. Minister of Health Regulation No. 73 of 2016 regulates the standards for pharmaceutical services in pharmacy includes the management standards for pharmaceutical preparations, medical devices and consumables, and clinical pharmacy services.

Regulations covering the aspect of Information System/Information Technology are regulated under 3 regulations with focus on electronic transaction and disclosure of public information. Law No. 11 of 2008 on Information and Electronic Transactions provides that Information Technology and Electronic Transaction utilization shall be implemented under the principles of legal certainty, benefit, prudence, good faith, and freedom to choose technology or technology neutrality. Further, Government Regulation No. 82 of 2012 on the Implementation of Electronic Transactions and Systems implementing in more details on the electronic system and transaction operation. Law No 14 of 2008 on Disclosure of Public Information regulates the procedures and requirements for disclosure of information to the public.

In relation to the health information system, there are 6 implementing regulations have been issued. Minister of Health Regulation No. 46 of 2017 on the National E-health Strategy provides the national e-health strategy is implemented through a framework that includes 7 (seven) components, namely: governance and leadership; strategy and investment; services and applications; standards and interoperability; infrastructure; regulation, policy, and policy fulfillment; and workforce. Minister of Health Regulation No. 92 of 2014 stipulates the implementation of data communications in the integrated Health Information System. The arrangement of data communication implementation in integrated Health Information System aims to guarantee the availability, quality, and access of priority Health Data and other Data Loads; optimize the flow of health data from districts/cities and/or provinces to the Ministry of Health or vice versa; and 
realize the implementation of an integrated Health Information System. Minister of Health Regulation No. 82 of 2013 defined the Hospital Management Information System as a communication information technology system that processes and integrates the entire hospital service process flow in the form of a network of coordination, reporting and administrative procedures to obtain information precisely and accurately, and is part of the Health Information System. Regulation of the Minister of Health No. 1171/Menkes/Per/VI/2011 regulates Hospital Information Systems as a process of collecting, processing, and presenting hospital data. Minister of Health Regulation No. 31 of 2019 requires the Community Health Center Information System should provide information to help the decision-making process in implementing community health center management in achieving its activity objectives. Regulation of the Minister of Health No. 20 of 2019 stipulates the implementation of Telemedicine services between health care facilities. Telemedicine carried out between one health care facility and another can be in the form of a consultation to diagnose, treat and/or prevent disease.

With respect to the handling of COVID-19, there are 5 regulations that have been issued by the government. Law No. 6 of 2018 defines Health Quarantine as an effort to prevent and ward off the entry or entry of diseases and/or public health risk factors that have the potential to cause public health emergencies. Government Regulation in Lieu of Law No 1 of 2020 stipulates state financial policy and financial system stability for handling COVID-19 pandemic and/or in the framework of facing threats that endanger the national economy and/or financial system stability. Government Regulation No. 21 of 2020 defines LargeScale Social Restrictions as restrictions on certain activities of residents in an area suspected of being infected with COVID-19 in such a way as to prevent the possibility of spreading COVID-I9. Presidential Decree No. 11 of 2020 stipulates COVID-19 as public health emergency. Minister of Health Regulation No. 9 of 2020 stipulates large-scale social restrictions where to be able to set large-scale social restrictions, a province/district/city must meet the following criteria: a. the number of cases and/or number of deaths due to disease has increased and spread significantly and rapidly to several regions; and $b$. there are epidemiological links with similar events in other regions or countries.

Based on Kang'a et al. (2017), strategies required for assuring sustainable implementation of electronic medical records (EMRs) consists of people, process, and technology. Handayani (2017) conducted a study of several public and private hospitals in Indonesia that identified several shortcomings of the current situation. Issues that should be solved namely (Handayani et al. 2017; Springer 2020; Yulisman 2020):

1. Technology: not all of the stakeholders in charge of managing health services appropriately use health information systems and technology; insufficient IT infrastructure (software, hardware, network, security); inadequate practices or standards in technology management, especially for data exchange and security (e.g. Health Insurance Portability and Accountability Act (HIPAA), International Organization for Standardization (ISO), etc.)

2. People: the number and competence of IT human resources currently available is inadequate

3. Process: regulations and best practices related to data privacy, information flow, the openness of public data and the use of digital technology has not been formulated in detail to optimize the delivery of health services (preventive, detection, curative, rehabilitative and monitoring); the pattern of coordination between agencies still needs to be detailed and formulate in regulations such as standard operating procedures related to the task and their roles, especially the role of data keeper, health data management that has not been thoroughly defined

4. Data: difficulty in obtaining integrated, accurate, real time and complete health data 


\begin{tabular}{|c|c|c|c|}
\hline$\underline{\text { Health Regulations }}$ & $\frac{\text { Information System/Information }}{\text { Technology Regulations }}$ & $\frac{\text { Health Information System }}{\text { Regulations }}$ & $\underline{\text { COVID-19 Regulations }}$ \\
\hline $\begin{array}{l}\text { - Presidential Regulation Number } \\
72 \text { of } 2012 \text { on the National Health } \\
\text { System. } \\
\text { - Minister of Health Regulation No. } \\
269 \text { of } 2008 \text { on Medical Records. } \\
\text { - Regulation of the Minister of } \\
\text { Health No. } 73 \text { of } 2016 \text { on } \\
\text { Pharmaceutical Services Standards } \\
\text { at Pharmacies. }\end{array}$ & $\begin{array}{l}\text { - Law Number } 11 \text { of } 2008 \text { on Information } \\
\text { - Lawd Electronic Transactions. } \\
\text { of Public Information. } \\
\text { - Government Regulation Number } 82 \text { of } \\
2012 \text { on the Implementation of } \\
\text { Electronic Transactions and Systems. }\end{array}$ & $\begin{array}{l}\text { - Minister of Health Regulation No. } 46 \text { of } \\
2017 \text { on the National E-health Strategy. } \\
\text { - Minister of Health Regulation No. } 92 \text { of } \\
2014 \text { on the Implementation of Data } \\
\text { Communications in the Integrated } \\
\text { Health Information System. } \\
\text { - Minister of Health Regulation No. } 82 \text { of } \\
2013 \text { on Hospital Management } \\
\text { Information System. } \\
\text { - Regulation of the Minister of Health } \\
\text { Number } 1171 / \text { Menkes/Per/VI/2011 on } \\
\text { Hospital Information Systems. } \\
\text { - Minister of Health Regulation No. } 31 \text { of } \\
2019 \text { on Community Health Center } \\
\text { Information System. } \\
\text { - Regulation of the Minister of Health } \\
\text { No. } 20 \text { of } 2019 \text { on the Implementation } \\
\text { of Telemedicine Services between } \\
\text { Health Care Facilities. }\end{array}$ & $\begin{array}{l}\text { - Law Number } 6 \text { of } 2018 \text { on Health } \\
\text { Quarantine. } \\
\text { - Government Regulation in Lieu of Law } \\
\text { Number } 1 \text { of } 2020 \text { on State Financial } \\
\text { Policy and Financial System Stability for } \\
\text { Handling COVID-19 Pandemic and/or in } \\
\text { the framework of facing threats that } \\
\text { endanger the National Economy and/or } \\
\text { Financial System Stability. } \\
\text { - Government Regulation No. } 21 \text { of } 2020 \text { on } \\
\text { Large-Scale Social Restrictions in the } \\
\text { framework of Accelerating the COVID-19 } \\
\text { Handling. } \\
\text { - Presidential Decree No. } 11 \text { of } 2020 \text { on } \\
\text { Stipulation of COVID-19 Public Health } \\
\text { Emergency. } \\
\text { - Minister of Health Regulation No. } 9 \text { of } \\
2020 \text { on Large-Scale Social Restrictions. }\end{array}$ \\
\hline
\end{tabular}

Figure 3. Indonesian Regulations Related to Health, IS/IT, and COVID-19

\section{ICT Recommendations}

Beauchamp and Childress (2001) proposed four principles of biomedical ethics. Schröder-Bäck et al. (2014) extended this philosophical basis to seven principles for public health ethics: non-maleficence, beneficence, health maximization, efficiency, respect for autonomy, justice, and proportionality. It is generally acknowledged that these ethics principles are largely compatible to different world views (e.g. Mustafa 2014) as well as with Indonesia's constitutional principles.

The goals and success of the Internet suggest considering similar design principles for a national e-health information system. Clark (1988) lists a primary goal, the choice of a federation of autonomous systems as opposed to the design of a centralized one, and seven second level goals: cost effectiveness, distribution, resilience and fault-tolerance, heterogeneity, openness and accountability. The recommendations are therefore made following the ethics and design principles indicated above for each of the intersections between the public health functions and the information system principles. The highest-level summary of recommendations is featured in Table 1 as a table of three time four themes. Further, this recommendation could be implemented both in the pandemic situation and in normal situation. 
Table 1. Summary of Recommendations

\begin{tabular}{|c|c|c|c|}
\hline & Assessment & Policy & Assurance \\
\hline People & $\begin{array}{lr}\text { Provide } & \text { adequate } \\
\text { number } & \text { of } \\
\text { surveillance people }\end{array}$ & $\begin{array}{l}\text { - Increase competency of } \\
\text { ICT human resources (i.e. } \\
\text { training) } \\
\text { - ICT literacy for society } \\
\text { - Training ICT researcher } \\
\text { and new artificial } \\
\text { intelligence technique for } \\
\text { health (i.e. master and } \\
\text { doctoral student) }\end{array}$ & $\begin{array}{l}\text { - Formulation of career path ICT } \\
\text { human resources in health care } \\
\text { facilities } \\
\text { - Increase the number of ICT } \\
\text { human resources }\end{array}$ \\
\hline $\begin{array}{l}\text { Proces } \\
\mathrm{S}\end{array}$ & $\begin{array}{l}\text { Formulate } \\
\text { integrated process } \\
\text { to collect } \\
\text { surveillance data } \\
\text { from existing health } \\
\text { technology }\end{array}$ & $\begin{array}{l}\text { - Information Center } \\
\text { formulation that can } \\
\text { manage data and process } \\
\text { flows for handling } \\
\text { epidemics and pandemics } \\
\text { (including managing hoax } \\
\text { information) } \\
\text { - Integrated health } \\
\text { information flow } \\
\text { regulation definition } \\
\text { - Putting e-health as part of } \\
\text { core research activities to } \\
\text { ensure continues research } \\
\text { and development of the } \\
\text { system }\end{array}$ & $\begin{array}{l}\text { - Determination of data standards } \\
\text { (i.e. format, interface, } \\
\text { interchange) that comply to } \\
\text { HIPAA, ISO, or others. } \\
\text { - Approval budgeting mechanism } \\
\text { for ICT spending in the event of } \\
\text { an emergency } \\
\text { - Information Technology and data } \\
\text { governance as well as enterprise } \\
\text { architecture (EA) formulation } \\
\text { which must refer to certain } \\
\text { standards such as Control } \\
\text { Objectives for Information } \\
\text { Technologies (COBIT), The } \\
\text { Open Group Architecture } \\
\text { Framework (TOGAF), etc. }\end{array}$ \\
\hline $\begin{array}{l}\text { Techn } \\
\text { ology }\end{array}$ & $\begin{array}{l}\text { Appropriate use of } \\
\text { digital technology } \\
\text { (i.e. electronic } \\
\text { medical records, } \\
\text { electronic } \\
\text { prescriptions, } \\
\text { hospital care } \\
\text { information system, } \\
\text { primary health, } \\
\text { information system, } \\
\text { mobile to hocial } \\
\text { telemedicine/telehe } \\
\text { alth, network) tond-to-end } \\
\text { optimize end-tilities } \\
\text { automated proceed } \\
\text { in health facilition }\end{array}$ & 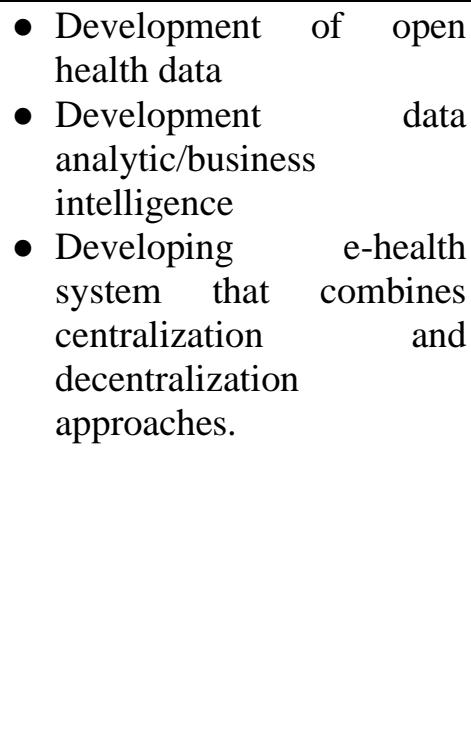 & $\begin{array}{l}\text { - ICT infrastructure improvement } \\
\text { (software, hardware, and } \\
\text { network) } \\
\text { - Preparing roadmap for e-health to } \\
\text { ensure incremental development } \\
\text { of e-health and its adoption in } \\
\text { health care practice }\end{array}$ \\
\hline Data & $\begin{array}{l}\text { Ensure the health } \\
\text { organization has } \\
\text { certification for } \\
\text { security and privacy }\end{array}$ & $\begin{array}{l}\text { - Improving system data } \\
\text { quality by involving the } \\
\text { community and } \\
\text { determining an appropriate } \\
\text { data approval mechanism }\end{array}$ & $\begin{array}{l}\text { - Data privacy by design } \\
\text { regulation formulation } \\
\text { - Ensure that the data is reliable } \\
\text { and trustworthy to enable } \\
\text { effective information exchange } \\
\text { and collaboration between } \\
\text { participating parties in e-health }\end{array}$ \\
\hline
\end{tabular}




\section{Discussion and Implications}

According to Figure 2 and consistent with Delone and McLean IS Success Model, the success of ICT implementation is largely determined by the quality of information, information systems and ICT services provided (Delone and McLean 2003). Further, in dealing with a pandemic, data surveillance is the basis for decision making in planning, implementing, monitoring, evaluating health programs and raising awareness and responding to extraordinary events that are fast and precise (Ghozali 2016). However, currently in Indonesia, it is still constrained by the small number of personnel who on charge in data surveillance (Ghozali 2016) and therefore the government and health organizations should provide adequate number of officers for data surveillance. Aside the number of surveillance human resource issue, the government should also formulate integrated process to collect and integrate surveillance data from existing health technology (i.e. electronic medical records, electronic prescriptions, hospital information system, primary care information system, mobile health, telemedicine/telehealth, social network). Hence, it is deem required for all health organizations to implement digital technology to optimize end-to-end automated proceed in health facilities. If these conditions can be satisfied, Indonesia could have an e-health system that can combine centralization and decentralization approaches. Centralization of standards is to achieve operability between different systems/health institutions, while the operation of the system can be decentralized and autonomous to promote system adoption and accommodate flexibility-especially in local health service level (Eason and Waterson 2013). It is required to improve ICT infrastructure and preparing roadmap for e-health to ensure incremental development of e-health and its adoption in health care practice to support the implementation of e-health system (Dixon 2007).

Further, Indonesia still has minimum number of ICT people in health industries (Oktara 2019). Therefore, the government and health organizations should increase the number of ICT human resources as well as formulation of career path ICT human resources in health care facilities. Moreover, the improvement of the quality of ICT human resources must also be supported by an increase in competence by providing ICTrelated training by experts from universities (i.e. master and doctoral student) in order they can follow the trends of scientific development. Also, putting e-heart as part of core research activities in the health organization and universities could ensure continuity of research and development of the system.

Due to the increasing number of health information specifically during the pandemic, the formation of an independent national information and telecommunication technology for e-health structure that involves representatives from the private sectors, academia and central and local governments are also required including to manage hoax information. Thus, government should also define a) integrated health information flow regulation; b) determination of data standards (i.e. format, interface, interchange) that comply with HIPAA, ISO, or others; c) Information Technology and data governance as well as EA. Moreover, to ensure the overall implementation of ICT, the government and health organizations also need to establish an approval budgeting mechanism for ICT emergency spending.

The Government of Indonesia has issued Presidential Regulation No. 39 of 2019 concerning One Data Indonesia to establish accurate, up to date, integrated, accountable, easily accessed, and shared data, and is managed carefully, integrated, and sustainably. That regulation is the basis for the establishment of open health data in Indonesia where data control and preserve will be conducted at the central and regional levels. To improve the data quality, it is also required the government and health organization could involve community and determining an appropriate data approval mechanism.

Further, based on the Presidential Regulation No. 39 of 2019 and the AHIMA Data Quality Management Model (AHIMA 2011), the data principles that must be referred to in the development of IS and open health data are 1) data accuracy: the extent to which the data are free of identifiable errors; 2) data accessibility: the level of ease and efficiency at which data are legally obtainable, within a well-protected and controlled environment; 3) data comprehensiveness: the extent to which all required data within the entire scope are collected, documenting intended exclusions; 4) data consistency: the extent to which the healthcare data are reliable, identical, and reproducible by different users across applications; 5) data currency: the extent to which data are up-to-date; a datum value is up-to-date if it is current for a specific point in time, and it is outdated if it was current at a preceding time but incorrect at a later time; 6) data definition: the specific 
meaning of a healthcare-related data element; 7) data granularity: the level of detail at which the attributes and characteristics of data quality in healthcare data are defined; 8) data precision: the degree to which measures support their purpose, and/or the closeness of two or more measures to each other; 9) data relevancy: the extent to which healthcare-related data are useful for the purposes for which they were collected; and 10) data timeliness: The availability of up-to-date data must be within the useful, operative, or indicated time. With the implementation of open health data, it is possible for governments and health organizations to develop analytic/business intelligence data. In addition, according to HIPAA, health organizations must have certification for security and privacy. Hence, data privacy by design regulation formulation is required to ensure the data is reliable and trustworthy to enable effective information exchange and collaboration between participating parties in e-health. Finally, to the best of our knowledge, few studies have been conducted to provide ICT recommendation for the development of e-health in Indonesia (Sudarto et al. 2018). Therefore, this study is expected to contribute ICT recommendations in formulating ICT policies to support government and health organization actions to overcome epidemics and pandemics.

\section{Conclusion}

We have proposed a methodology for the formulation of recommendations for the further development of a robust national e-health strategy from the point of view of ICT. The recommendations that we indicate in this paper are current but neither permanent nor complete as the public health landscape evolves. They illustrate the operationality of methodology. The methodology caters for this need for evolution and adaptability.

It appears to us, however, that the diversity and level of expertise needed to formulate such recommendations and plans in a timely manner requires the formation of an independent national information and telecommunication technology for e-health structure that involves representatives of the private sector, of academia and of central and local governments. We envision the role of such a structure to be the definition (policy), the evaluation (assessment) and the enforcement (assurance) of national open standards for e-health and the definition and promotion of a research roadmap, through the funding fundamental research and translational research projects. The structure, following our proposed methodology, should be concerned with people, processes, technologies, and data involved in public health from the information and telecommunication technology perspective. The national standards should guarantee the quality and availability of human resources and the effective and efficient interoperability of autonomous but open components of the national e-health system developed by the private sector, central and local governments as well as other national and international entities. The structure should also advise the government on decisions concerning the necessary compromises highlighted such as the balance between openness of the data and privacy for the citizens. The limitation of this study that we do not involve the health regulators and private health organizations; thus, future studies should enrich this study by involving all relevant health stakeholders to have better insights.

\section{Acknowledgement}

This work was partially funded by the project Intelligent Data Science for Contact Tracing and Outbreak Investigation under the NUS COVID-19 Research Seed Funding (Grant reference number: NUSCOVID19RG-40).

\section{References}

AHIMA. 2011. Pocket Glossary of Health Information Management and Technology, (3 ${ }^{\text {rd }}$ ed.), AHIMA Press.

Bardhan, I., Chen, H., and Karahanna, E. 2020. "Connecting Systems, Data, and People: A Multidisciplinary Research Roadmap for Chronic Disease Management," Management Information Systems Quarterly (44:1), pp. 185-200.

Beauchamp, T. L., and Childress, J. F. 2001. Principles of Biomedical Ethics, ( $5^{\text {th }}$ ed.), New York: Oxford University Press. 
Clark, D. 1988. "The Design Philosophy of the DARPA Internet Protocols," ACM SIGCOMM Computer Communication Review (18:4), pp. 106-114.

D'Auria, G., and De Smet, A. 2020. "Leadership in a Crisis: Responding to the Coronavirus Outbreak and Future Challenges," McKinsey. (https://www.mckinsey.com/business-functions/organization/ourinsights/leadership-in-a-crisis-responding-to-the-coronavirus-outbreak-and-future-challenges, accessed April 7, 2020).

Delone, W.H., and McLean, E. R. 2003. "The DeLone and McLean Model of Information Systems Success: A Ten-Year Update," Journal of Management Information Systems (19:4), pp. 9-30.

Deloitte Indonesia, Bahar Law Firm, and Chapters Indonesia. (n.d.). "21st Century Health Care Challenges: A Connected Health Approach Megatrends in Health Care," 2019: Deloitte Indonesia. (www2.deloitte.com/content/dam/Deloitte/id/Documents/public-sector/id-gps-ehealthpublication-Indonesia.pdf).

Dixon, B. E. 2007. "A Roadmap for the Adoption of e-Health," e-Service Journal (5), pp. 3-13.

Eason, K., and Waterson, P. 2013. "The implications of e-health system delivery strategies for integrated healthcare: Lessons from England," International Journal of Medical Informatics (82), pp. 96-106.

Ghozali, J. A. A. 2016. "Evaluasi Kegiatan Surveilans Epidemiologi Di Pelabuhan Dalam Upaya Pencegahan Wabah Flu Burung (Studi Kasus Di Pelabuhan Malundung KKP Kelas II Tarakan)," The Indonesian Journal of Public Health (11:1), pp. 99-109.

Gugus Tugas Percepatan Penanganan COVID-19. (n.d.). "Data Sebaran," 2020: Gugus Tugas Percepatan Penanganan COVID-19. (https://covid19.go.id/, accessed July 1, 2020).

Handayani, P. W., Hidayanto, A. N., Pinem, A. A., Hapsari, I. C., Sandhyaduhita, P. I., and Budi, I. 2017. "Acceptance Model of a Hospital Information System," International Journal of Medical Informatics (99), pp. 11-28.

IMO. 1998. From Generation to Generation: The Health and Well-Being of Children in Immigrant Families, The National Academies Collection: Reports Funded by National Institutes of Health, $\begin{array}{lllll}\text { Washington } & \text { (DC): } & \text { National }\end{array}$ (http://www.ncbi.nlm.nih.gov/books/NBK230361/).

Kang'a, S. G., Muthee, V. M., Liku, N., Too, D., and Puttkammer, N. 2017. "People, Process and Technology: Strategies for Assuring Sustainable Implementation of EMRs at Public-Sector Health Facilities in Kenya," AMIA Annual Symposium Proceedings (2016), pp. 677-685.

Mahendradhata, Y., Trisnantoro, L., Listyadewi, S., Soewondo, P., Marthias, T., Harimurti, P., and Prawira, J. 2017. "The Republic of Indonesia Health System Review," Health Systems in Transition (7:1), Asia Pacific Observatory on Health Systems and Policies, (K. Hort and W. Patcharanarumol, eds.).

Mustafa, Y. 2014. "Islam and the Four Principles of Medical Ethics," Journal of Medical Ethics (40:7), Institute of Medical Ethics, pp. 479-483.

Nugraha, D. C. A., and Aknuranda, I. 2017. "An Overview of E-Health in Indonesia: Past and Present Applications," International Journal of Electrical and Computer Engineering (IJECE) (7:5), pp. 2441-2450..

Oktara, Diko. "Kebutuhan Ahli Teknologi Informasi Banyak, Tawaran Gaji Pun Wow," Tempo. (https://gaya.tempo.co/read/1267798/kebutuhan-ahli-teknologi-informasi-banyak-tawaran-gajipun-wow, accessed July 1, 2020).

Schröder-Bäck, P., Duncan, P., Sherlaw, W., Brall, C., and Czabanowska, K. 2014. "Teaching Seven Principles for Public Health Ethics: Towards a Curriculum for a Short Course on Ethics in Public Health Programmes," BMC Medical Ethics (15:1), p. 73.

Silver, M. S., Markus, M. L., and Beath, C. M. 1995. "The Information Technology Interaction Model: A Foundation for the MBA Core Course," MIS Quarterly (19:3), Management Information Systems Research Center, University of Minnesota, pp. 361-390.

Springer, K. 2020. "How COVID-19 Will Dampen Indonesia's Infrastructure Developments," The Jakarta Post. (https://www.thejakartapost.com/academia/2020/05/02/how-covid-19-will-dampenindonesias-infrastructure-developments.html, accessed July 7, 2020).

Sudarto, F., Kristiadi, D. P., Warnars, H. L. H. S., Ricky, M. Y., and Hashimoto, K. 2018. "Developing of Indonesian Intelligent e-Health Model," Indonesian Association for Pattern Recognition (INAPR) Proceedings (2018), pp. 307-314. 
United States of America Center for Disease Control and Prevention. 2011. "Core Functions of Public Health and How They Relate to the 10 Essential Services." (https://www.cdc.gov/nceh/ehs/ephli/core_ess.htm, accessed July 5, 2020).

WHO. 2017. WHO Guidance for Surveillance during an Influenza Pandemic: Update 2017, Global Influenza Programme, World Health Organization. (https://www.who.int/influenza/preparedness/pandemic/WHO_Guidance_for_surveillance_durin g_an_influenza_pandemic_082017.pdf).

Yulisman, L. 2020. "Indonesia Probes Alleged Hacking of Covid-19 Test Data," The Straits Times. (https://www.straitstimes.com/asia/se-asia/indonesia-probes-alleged-hack-of-covid-19-test-data, accessed July 5, 2020).

\section{How to cite:}

Handayani, P. W., Yazid, S., Bressan, S., and Sampe, A. F. 2020. "Information and Communication Technology Recommendations for the Further Development of a Robust National Electronic Health Strategy for Epidemics and Pandemics," Jurnal Sistem Informasi (Journal of Information System) (16:2), pp. 31-42. 